\title{
Development of Virtual Artistic Gymnastics-Based Competitions in Central Java
}

\author{
Agus Darmawan ${ }^{1}$, Tommy Soenyoto ${ }^{2}$, Dwi Tiga Putri ${ }^{3}$, Agus Pujianto ${ }^{4}$ \\ \{agusputri12@mail.unnes.ac.id ${ }^{1}$, tommysoenyoto@mail.unnes.ac.id ${ }^{2}$, dwitgaputri@mail.unnes.ac.id ${ }^{3}$ \} \\ Universitas Negeri Semarang, Semarang, Indonesia ${ }^{1,2,3}$
}

\begin{abstract}
This study aimed to determine how a virtual-based competition development model for Artistic gymnastics competitions in Central Java. The research method uses a research design and a developer. Who involved the subjects of 29 PERSANI Pengcab throughout Central Java in this study. These experts use media experts and the wait and care technology for artistic gymnastics, PERSANI, Central Java. The research results resulted in a virtual competition system model that can be used as a means of artistic gymnastics competition in Central Java. Media experts and gymnastics claim the system's success and utility rate at $90 \%$. The interviews with PERSANI Pengcab administrators throughout Central Java stated that all Pengcab officials stated that this system model could be applied in Central Java. This study concludes that the artistic gymnastics competition model developed can be used for artistic gymnastics competitions in Central Java during the Covid-19 pandemic.
\end{abstract}

Keywords: Development, virtual artistic gymnastics, competitions.

\section{Introduction}

Almost 2 years the world has faced a viral pandemic which presents a serious threat to human health. Since the outbreak was first discovered in Wuhan, China, in December 2019, the coronavirus disease 2019 (COVID-19) has spread rapidly globally. COVID-19 has been declared a pandemic by the World Health Organization (WHO) as confirmed cases are approaching 200,000 patients with what will exceed 8000 deaths in more than 160 countries [1], [2], [3]. COVID-19 has proven to be a pandemic that can bring society, the economy and education to its knees [4]. As of March 2020, several countries banned unnecessary outdoor activities during COVID-19, which is commonly called a 'lockdown'. This lockdown has the potential to have an impact on the level of associated physical activity, among others, a significant impact especially on the gymnastic situation [5], [6].

Guidance and development of elite sports are arranged in a planned, systematic, tiered and sustainable manner in order to achieve national sports achievements. In the era of the Covid19 pandemic, the coaching system is said to have decreased, as was the implementation of the National Sports Week which was postponed, including coaching at sports clubs because of concerns about the risk of covid-19 transmission [7], [8]. The coaching carried out by the sports club has also experienced obstacles. The implementation of a routine training schedule is also limited by the maximum number, so that the training schedule is disrupted [9]. Covid19 has had a major impact on the coaching and management system of sports coaching, the implementation of physical activity has also decreased. Training schedules that have 
decreased in quality and quantity of training have disrupted the coaching system [10]. A reduction in the frequency of training causes the athlete's muscle strength and endurance to decrease. The significant decrease occurred due to the decreased duration of exercise [11], [12]. The mental toughness of a gymnast is basically related to various things, one of which is the problem of self-confidence, the factor of self-confidence is a very important part, considering that there are so many mainstay techniques of movement in this sport that require athletes to have courage, as an impact of movement patterns that must be used. Doing so has a high enough risk, besides that gymnastics athletes who will take part in the championship in 2020 must bury their dreams of achieving achievements due to the pandemic, the government has adopted a policy of banning crowds so that all championships in sports do not get permission and cannot be carried out like the previous year [13]. Latency determines not only how players experience online gameplay but also how to design the games to mitigate its effects and meet player expectations. Issues pertaining to the production and consumption of corporate websites and online games remain relatively unexplored. [14], [15]

In the era of the COVID-19 pandemic there was no championship held from PERSANI Central Java, so the problems to be studied were: How to develop an effective and efficient virtual competition system based on artistic gymnastics in the pandemic era?

\section{Methods}

The type of research that will be used is Research and Development (R\&D) research. This study aims to develop a new product or improve existing products, in this case, to develop a virtual-based artistic gymnastics competition system.

This research stage uses the following R\&D development steps:

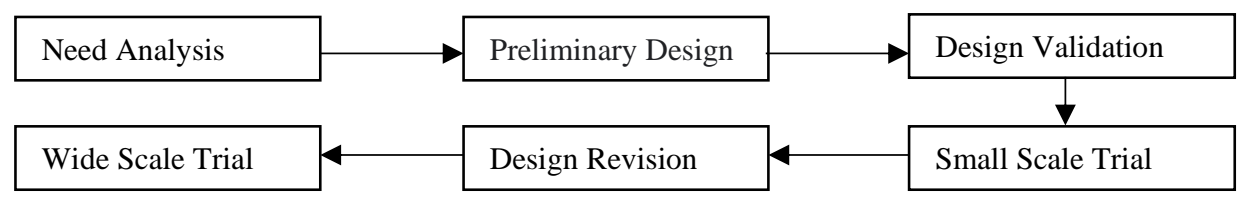

Fig. 1. Research stage

The subjects in this study were all of the 29 Pengkab / Pengkot Districts / Pengkot PERSANI throughout Central Java. The experts involved in the implementation of research and development were 2 gymnastics experts and 2 IT experts. The small scale trial will involve 1 karesidenan (Karesidenan Semarang). For a wide scale test the entire residency will be used.

The data collected came from material experts as material validators, IT experts as validators for the championship system model, and PERSANI City Government / Pengkab in Central Java as respondents to assess the virtual-based competition system. Data collection techniques to assess the feasibility of this virtual-based championship system are by using a questionnaire or questionnaire. Questionnaire or questionnaire is a technique or method of collecting data indirectly (researchers do not directly ask and answer questions with respondents). The instrument or data collection tool is in the form of a questionnaire containing a number of questions that must be answered or responded to by the respondent. 


\section{Result and Discussion}

The result of this research is to produce a sofwere design that is used for artistic gymnastics competitions in Central Java. This software is used by the jury in making an assessment. The specifications of the software is:

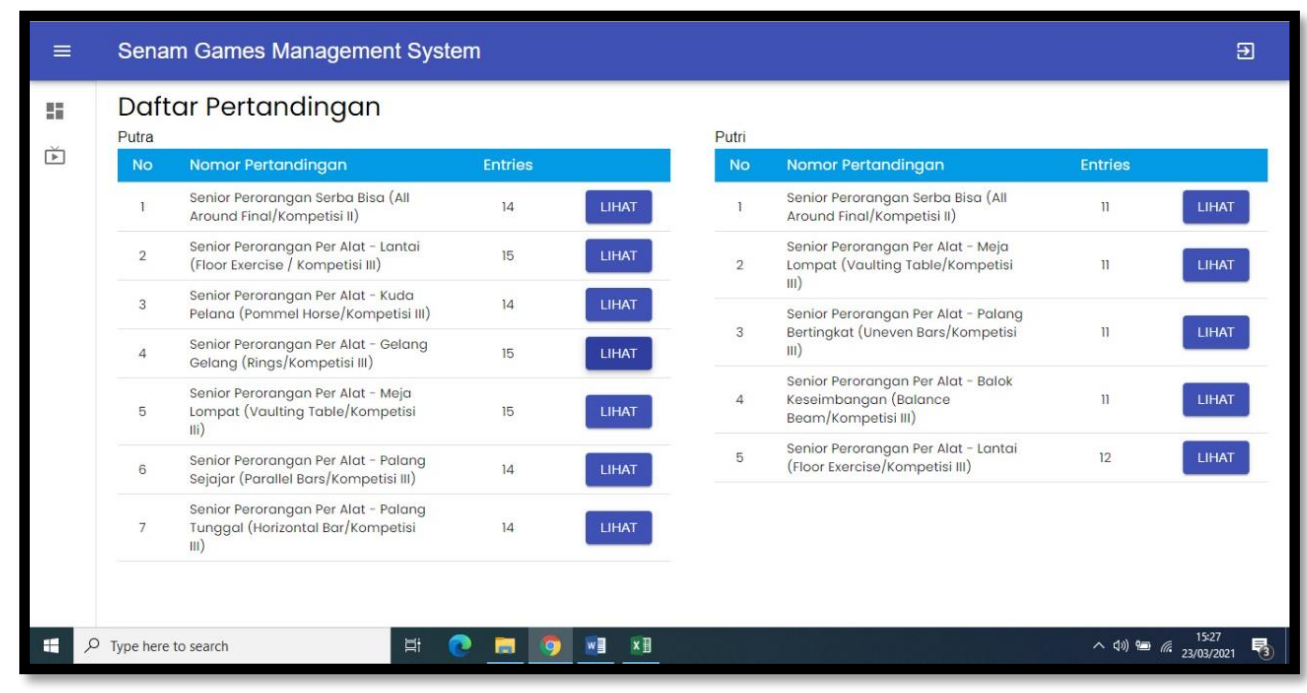

Fig. 2. Gymnastics games management system

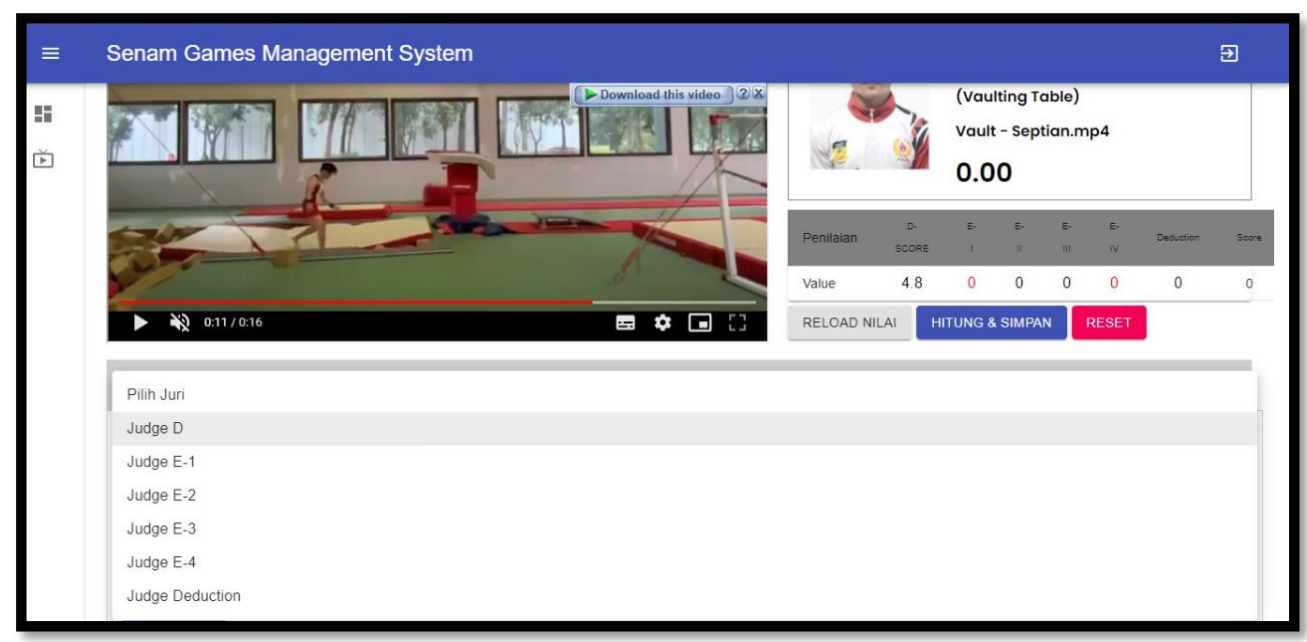

Fig. 3. Gymnastics games management system

Based on figure 2 and 3, it is explained that the results of the development are in the form of an online judging activity application. The video file was sent in advance from the coach or respective official, then the committee recapitulated the video and entered it into the online 
judging system. The judges in charge will have their own accounts that can be used to play videos as well as provide direct assessments of the system.

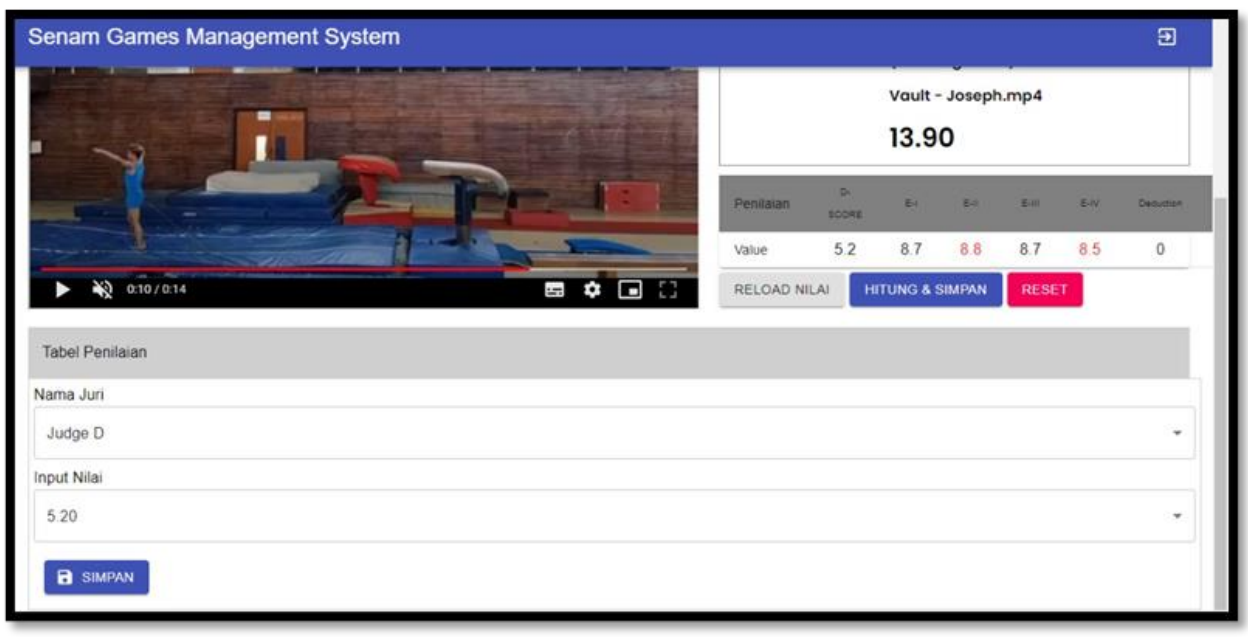

Fig. 4. D Judge system

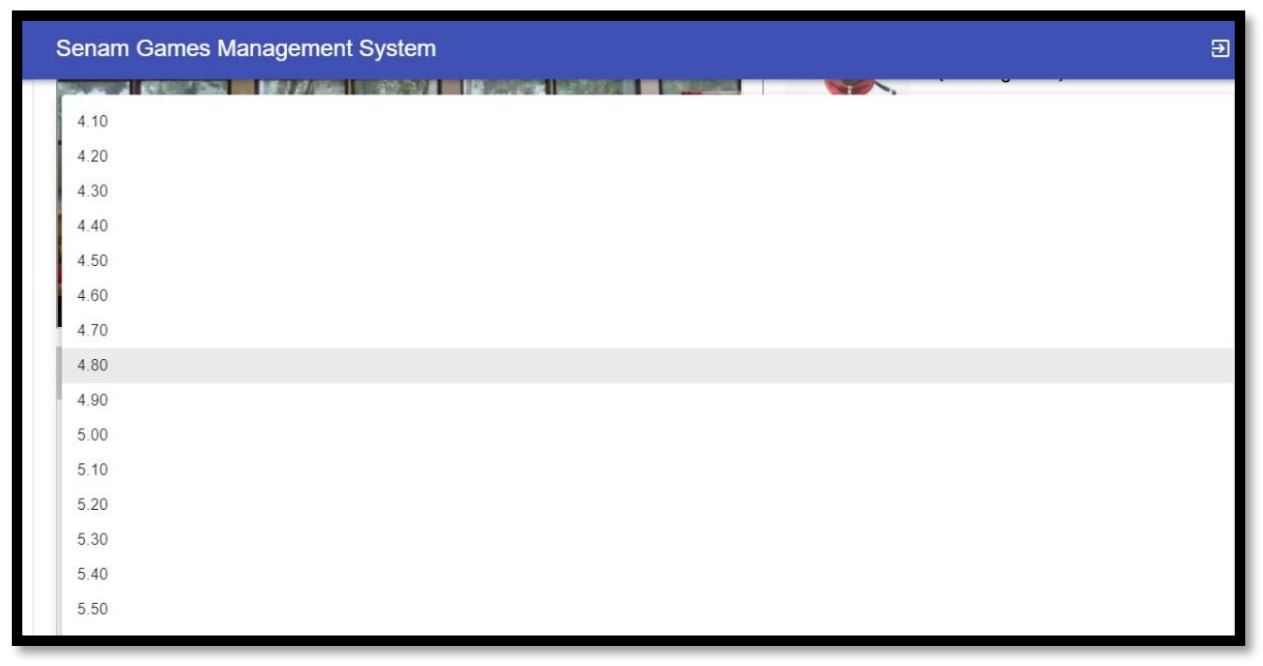

Fig. 5. Scoring D judge system

Figures 3 and 4 show the activities carried out by the judges when conducting the assessment. In the scouring system, the jury evaluates simultaneously and at one time. Judging is carried out by each panel, both jury D and E through this system. Based on validation activities carried out by experts, it can be analyzed and it can be concluded that the expert gives a score of $90 \%$ this virtual competition system can be used in Central Java. The system is very interesting, it can even be applied to the championship oflline. This is reinforced by the 
results of interviews conducted with coaches, administrators and judges in Central Java who stated that this system is very helpful in the judging process and the competition system in Central Java.

\section{Conclusion}

From the results of the research conducted, it is found that the developed model of the online-based competition system can be implemented and implemented for artistic gymnastics championships in Central Java. This system has many advantages that can be obtained when an online championship is held with a system management championship system.

\section{References}

[1] Fraser, N., Brierley, L., Dey, G., Polka, J. K., Pálfy, M., Nanni, F., \& Coates, J. A. Preprinting the COVID-19 pandemic. BioRxiv. 2020.

[2] Pellino, G., \& Spinelli, A. How coronavirus disease 2019 outbreak is impacting colorectal cancer patients in Italy: a long shadow beyond infection. Diseases of the Colon \& Rectum. 2020; 63(6): 720-722.

[3] Spinelli, A., \& Pellino, G. COVID-19 pandemic: perspectives on an unfolding crisis. Journal of British Surgery. 2020; 107(7): 785-787.

[4] Škare, M., Soriano, D. R., \& Porada-Rochoń, M. Impact of COVID-19 on the travel and tourism industry. Technological Forecasting and Social Change. 2021; 163: 120469.

[5] Stockwell, S., Trott, M., Tully, M., Shin, J., Barnett, Y., Butler, L., \& Smith, L. Changes in physical activity and sedentary behaviours from before to during the COVID-19 pandemic lockdown: a systematic review. BMJ Open Sport \& Exercise Medicine. 2021; 7(1): e000960.

[6] Drewes, M., Daumann, F., \& Follert, F. Exploring the sports economic impact of COVID-19 on professional soccer. Soccer \& Society. 2021; 22(1-2): 125-137.

[7] Rahadian, A. Atlet Elit, Performa Prestasi ditengah Pandemi Covid-19. 2021.

[8] Iswahyudi, F. JAMINAN PERLINDUNGAN BAGI PELAKU OLAH RAGA DALAM MASA PANDEMI COVID-19. BULETIN KONSTITUSI. 2021; 1(1).

[9] Anggraeni, Y. F., \& Purnomo, M. ANALISIS MANAJEMEN LATIHAN PB SURYABAJA TULUNGAGUNG SELAMA MASA PANDEMI COVID-19. Jurnal Prestasi Olahraga. 2021; 4(3): 107-112.

[10] Widodo, Z. D., Rumaningsih, M., \& Sulistiyono, M. N. Impresi Covid-19 Terhadap Manajemen Organisasi dan Pembinaan Prestasi Cabang Olahraga Pencak Silat di Surakarta. JURNAL WIDYA GANECWARA. 2020; 10(4).

[11] Nugraha, P., Utama, M., S, A., \& Sulaiman, A. Survey Of Students Sport Activity During Covid19 Pandemic. Jp.Jok (Jurnal Pendidikan Jasmani, Olahraga Dan Kesehatan). 2020; 4(1): 11-24. https://doi.org/10.33503/jp.jok.v4i1.805

[12] Muchlas, M. Evaluation Of Strength, Resistance And Balance During The Covid-19 Pandemic. In Prosiding SENOPATI (Seminar Olahraga Dalam Pendidikan Teknologi dan Inovasi). 2020; 1 (1): $22-28$

[13] Ningsih, B. Tingkat Motivasi Berprestasi Atlet Gymnastic Persani Jambi Dalam Menghadapi POPNAS XVI 2021 (Doctoral dissertation, Universitas Jambi). 2021

[14] Claypool, M., \& Claypool, K. Latency and player actions in online games. Communications of the ACM. 2006; 49(11): 40-45.

[15] Scherer, J. Globalization, promotional culture and the production/consumption of online games: engaging Adidas'sBeat Rugby'Campaign. New Media \& Society. 2007; 9(3): 475-496. 